\title{
INFLUENCE OF MARINADES ON SHEAR FORCE, STRUCTURE AND SENSORY PROPERTIES OF HOME-STYLE JERKY
}

\author{
Joanna Żochowska-Kujawska ${ }^{凶}$, Marek Kotowicz, Kazimierz Lachowicz, \\ Małgorzata Sobczak
}

Department of Meat Technology, West Pomeranian University of Technology in Szczecin

K. Królewicza 4, 71-550 Szczecin, Poland

\begin{abstract}
Background. Products from dried meat have been sold for many years as snack foods. The most important sensory attributes of this type of food are texture and flavour, determined by the selection of the raw material and the effect of numerous technological factors. The aim of the study was to investigate the structure, sensory and mechanical properties of meat snacks produced under non-commercial conditions using wild boar, roe deer and beef as raw material.

Material and methods. Jerky was prepared from Longissimus muscle treated $\left(24 \mathrm{~h}, 4^{\circ} \mathrm{C}\right)$ with the following marinades before drying at $55^{\circ} \mathrm{C}$ for $6 \mathrm{~h}$ : (a) spices, (b) lemon \& honey marinade, (c) marinating with balsamic vinegar marinade, (d) dipping into pineapple marinade, and (e) using ginger marinade. The jerky's shear and work forces, structure and sensory properties were compared.

Results. An increase in sensory properties and a decrease in WB parameters as a consequence in muscle structural elements changes were found in all marinate-treated samples compared to the control. The greatest changes were observed when the meat was soaked with pineapple marinade before drying. Lower ones were observed when ginger and balsamic vinegar marinades were applying, and the lowest when jerky was produced using lemon \& honey. Roe deer jerky, compared to wild boar and beef, received better scores for texture, and worse for overall acceptability.

Conclusion. Marinades containing proteolytic enzymes or characterized by a low $\mathrm{pH}$ could be used as tenderizers in jerky production from initially tough meat such as wild boar, and marinades based on lemon \& honey and also vinegar could be used for flavoring tender meat with an intense aroma, such as roe deer meat.
\end{abstract}

Keywords: jerky, roe deer, wild boar, structure, Warner-Bratzler parameters

\section{INTRODUCTION}

Products from dried meat, commonly referred to as "jerky" because of the characteristic appearance of the final products, have been sold for many years as snack foods, primarily in the USA (Albright et al., 2000). Nowadays, dried meat snacks continue to grow in popularity (Scheinberg et al., 2014; Sloan, 2011) and may also be an attractive product for the Polish consumer, especially for the young people, primarily students (Konieczny et al., 2007). The most important sensory attributes of this type of food are texture, colour and flavour, which are determined by the selection of the raw material and the effect of numerous technological factors (Albright et al., 2000). Jerkies are usually prepared from different kind of meat (beef, pork, poultry, venison, and fish), with spices and other functional additives, or with individual technological

『joanna.zochowska-kujawska@zut.edu.pl 
procedures (Albright et al., 2000; Konieczny et al., 2007).

The use of game in meat technology is worth emphasizing, especially since consumer interest in game meat as an alternative to pork and beef has grown in recent years. The reason for the increase in consumption of venison is its high nutritional value. Thus, cured and dried products from different game species have appeared on the market (Paleari et al., 2000; Soriano et al., 2006). It is widely acknowledged that venison's lack of rich fat, a little thicker connective tissue and/or higher amount of red fibres, compared to pork meat, for example, can cause it to become tough (Sales and Kotrba, 2013; Żochowska-Kujawska et al., 2009). In order to obtain tender and juicy meat, it could be marinated in an acidic solution. Consequently, $\mathrm{pH}$-induced swelling of muscle fibres and/or connective tissue, accelerated proteolytic weakening of muscle structure, and finally increased solubilization of collagen upon cooking were observed (Żochowska-Kujawska et al., 2012).

The study presented here aimed to compare the effect of marinades and meat types on changes in the structure, shear force value and sensory properties of meat snacks.

\section{MATERIAL AND METHODS}

\section{Raw material}

The raw material for the investigations was beef, and venison such as roe deer and wild boar. The beef was obtained from BW $\times$ Angus crossbreed (about 24 months of age), whereas the venison came from a total of 10 male wild boars and roe deer ( 5 animals of each species) which had been hunted during autumn in the forests of the Poland's Western Pomeranian region and kept at $4{ }^{\circ} \mathrm{C}$ for $48 \mathrm{~h}$ after being shot. The carcass weights of the wild boar and roe deer were 35 $\pm 3 \mathrm{~kg}$ and $13 \pm 1 \mathrm{~kg}$ respectively, while their ages were about 2 years. The carcasses were used to obtain loins of $\mathrm{pH}$ 5.7-5.8. The lean meat from the Longissimus lumborum muscles of each species was sliced separately into strips of about $10 \times 10 \times 100 \mathrm{~mm}$. The muscle strips were divided into five batches (within each species), salted with $2 \%$ of $\mathrm{NaCl}$ and then subjected to the following predrying treatments: (I) seasoning, (II) lemon \& honey marinade (pH 4.8), (III) marination with balsamic vinegar marinade ( $\mathrm{pH} 4.4)$, (IV) dipping into pineapple marinade ( $\mathrm{pH} 4.1$ ) and (V) using ginger marinade $(\mathrm{pH} 4.7)$. The seasoning mixture contained marjoram, thyme, lemon pepper, oregano, basil and garlic powder. $100 \mathrm{ml}$ of the lemon \& honey marinade consisted of $30 \mathrm{ml}$ of honey, $25 \mathrm{ml}$ of fresh lemon juice, $10 \mathrm{ml}$ of soy sauce, $0.6 \mathrm{~g}$ black pepper, and $35 \mathrm{ml}$ of water. The vinegar marinade was prepared as follows: $30 \mathrm{ml}$ of light soy sauce, $10 \mathrm{ml}$ of Dijon mustard, $10 \mathrm{ml}$ of balsamic vinegar, $50 \mathrm{ml}$ of water, $4 \mathrm{~g}$ of brown sugar, 0.6 of black pepper. The pineapple marinade consisted of $30 \mathrm{ml}$ of fresh pineapple juice, $10 \mathrm{ml}$ of soy sauce, $2 \mathrm{ml}$ of balsamic vinegar, $58 \mathrm{ml}$ of water and $0.6 \mathrm{~g}$ of black pepper, $0.5 \mathrm{~g}$ of red pepper flakes, and $0.5 \mathrm{~g}$ of garlic powder. Finally, the ginger marinade was prepared using $20 \mathrm{ml}$ of soy sauce, $20 \mathrm{ml}$ of lime juice, $20 \mathrm{ml}$ of fresh grated ginger, $40 \mathrm{ml}$ of water and $1.5 \mathrm{~g}$ of crushed red pepper. Each mixture was added to muscle strips at $5 \%$ by dipping the meat into a marinade at $4 \pm 1^{\circ} \mathrm{C}$ for $24 \mathrm{~h}$ prior to drying at $55 \pm 2^{\circ} \mathrm{C}$. A Zelmer FD1002 drier for mushrooms, fruits and vegetables was used. In order to prevent the product from overheating, grids were changed on a rotation basis. Unpublished data from our laboratory shows that meat slices reach the appropriate quality within 5.5-6 h of drying. Thus the total drying time of the product under these conditions did not exceed $6 \mathrm{~h}$, and at the same time, the jerky's water activity was about $0.71-0.68$, depending on the marinating method.

\section{Structure}

The mean fibre cross-sectional area (CSA), perimysium and endomysium thickness, and the area of intramuscular fat (IMF) were measured on ready-to-eat jerky cut from the middle part of snacks. Three cuts were taken from each batch. The samples were dehydrated in alcohol, fixed in a Sannomiya solution, and embedded in paraffin blocks. The blocks were sectioned into 10 $\mu \mathrm{m}$ slices with a microtome. The sections were placed on glass slides, contrast-stained with hematoxylin and eosin, and sealed with Canada balsam (Burck, 1975). The Multi Scan Base v. 13 computer image analysis software was used to measure fibre CSA, as well as perimysium and endomysium thickness per muscle fibre bundle, and 10 primary muscle fibre bundles per each sample were analysed, in addition to more than 200 muscle fibre and perimysium and endomysium 
thickness/samples. The amount of intramuscular fat was counted on an area of the muscle tissue section (about $0.25 \mathrm{~cm}^{2}$ ).

\section{Warner-Bratzler test}

Jerky shear and work forces were assayed in accordance with the Warner-Bratzler (WB) procedures with a computer-interfaced Instron 1140. Dried products of about $0.6 \times 0.6 \times 70 \mathrm{~mm}$ were cut by a triangular knife perpendicular to the muscle fibre using a crosshead speed of $50 \mathrm{~mm} \mathrm{~min}^{-1}$ and a load cell of $500 \mathrm{~N}$ (Bourne, 1982). The WB test was repeated 12-15 times on each kind of jerky.

\section{Sensory properties}

The sensory evaluation of the jerky samples was assessed by a trained expert panel of 5 members with a minimum of four years' experience in texture analysis of meat and meat products. The jerky's tenderness, chewiness, juiciness, stringiness, perceptibility of connective tissue, palatability, and overall attractiveness were assessed using a 6-point scale as follows: 1 point: the least tender, and samples with the low juiciness, stringiness, connective tissue perceptibility, chewiness, palatability and overall attractiveness; 6 points: the most tender, juicy, stringy, and with the highest connective tissue perceptibility, chewiness, palatability and overall attractiveness.

\section{Statistical analysis}

The instrumental measurement data were analysed statistically using Statistica ${ }^{\circledR}$ v.12.0 PL software, with the single effects given by marinade or meat species and the fixed effects by marinade, meat species and their interaction. Tables 1-2 present the mean values and standard deviation (SD) for each sample, as well as the differences in mechanical properties and structure between jerkies produced with different marinades or with different meat species. The RIR-Tukey test was used for this statistical analysis.

\section{RESULTS AND DISCUSSION}

The results of the analyses performed (Table 1) show significant $(P<0.05)$ effects of species on mean values of structural elements of jerky. It was found that among the jerky samples, beef products Longissimus muscle consisted of fibres with a higher cross-sectional area (CSA; by approximately 20-35\%) and with the thickest perimysium (by about 19-51\%) compared to those obtained from wild boar and roe deer. This was found to be true regardless of the marinating methods. The thickest endomysium was typical for wild boar jerky (approx. 10-58\% thicker than other samples), and the highest area of intramuscular fat (by about 26-79\%) was observed in products obtained from roe deer meat. Żochowska-Kujawska et al. (2009) also compared SM muscle from different species of wild animals and reported thicker connective tissue in wild boar than deer muscle. Meat marinating was found to induce a small decrease in fibre CSA, as well as the endomysium and perimysium thickness compared to jerky samples produced with spices (control). It was also shown that marinating applied before drying the meat resulted in the greatest changes in endomysium thickness compared to other structural elements. However, no significant effects of different meat species on changes in structural element values of jerky after marinating were found (Table 1). A probable reason for the small differences in the structural elements between samples of jerky produced from different species of animals was the fact that in our studies dehydrated meat was used for structure analysis, not a meat taken directly from marinades. Żochowska-Kujawska et al. (2012) compared the structure of wild boar and deer muscle not thermally treated and marinated in different ways and found differences between the species.

When the marinating method was considered, the greatest changes in structural elements were observed during marinating with pineapple and ginger compared to other methods. Moreover, the effect of exogenous enzymes on the connective tissue was highest during marinating with pineapple juice compared to ginger (Table 1). A reason for the connective tissue thickness changes could be that some plant enzymes can hydrolyze collagen and elastin (Wada et al., 2002), which helps to tenderize meat that is especially rich in connective tissue, such as beef or venison meat. Ketnawa et al. (2010) also confirmed that bromelain from pineapple peel can extensively degrade the collagen from beef and giant catfish skin. According to Ashie et al. (2002), bromelain exhibits a more accentuated hydrolytic action on collagen than on myofibrillar proteins. The mechanism of weakening is unclear, 
Żochowska-Kujawska, J., Kotowicz, M., Lachowicz, K., Sobczak, M. (2017). Influence of marinades on shear force, structure and sensory properties of home-style jerky. Acta Sci. Pol. Technol. Aliment., 16(4), 413-420. http://dx.doi.org/10.17306/J.AFS.2017.0508

Table 1. Mean values of structural elements of beef, wild boar and roe deer jerky produced with different marinades

\begin{tabular}{|c|c|c|c|c|c|c|c|c|c|}
\hline \multirow[t]{2}{*}{ Marinade } & \multirow[t]{2}{*}{$\begin{array}{c}\text { Meat } \\
\text { species }\end{array}$} & \multicolumn{2}{|c|}{$\begin{array}{c}\text { Muscle fibre } \\
\text { cross-sectional area } \\
\mu \mathrm{m}^{2}\end{array}$} & \multicolumn{2}{|c|}{$\begin{array}{l}\text { Perimysium thickness } \\
\qquad \mu \mathrm{m}\end{array}$} & \multicolumn{2}{|c|}{$\begin{array}{l}\text { Endomysium thickness } \\
\qquad \mu \mathrm{m}\end{array}$} & \multicolumn{2}{|c|}{$\begin{array}{c}\text { Intramuscular fat area } \\
\mu \mathrm{m}^{2}\end{array}$} \\
\hline & & mean & SD & mean & SD & mean & SD & mean & SD \\
\hline \multirow[t]{3}{*}{ Spices } & beef & $1441.15_{1}^{\mathrm{a}}$ & 52.21 & $22.74_{1}^{a}$ & 1.48 & $2.36_{1}^{\mathrm{b}}$ & 0.07 & $152174_{2}^{\mathrm{c}}$ & 23452 \\
\hline & wild boar & $1154.12_{1}^{\mathrm{b}}$ & 48.58 & $17.92_{1}^{\mathrm{b}}$ & 2.15 & $2.71_{1}^{\mathrm{a}}$ & 0.06 & $203622_{3}^{\mathrm{b}}$ & 16027 \\
\hline & roe deer & $930.56_{1}^{c}$ & 61.15 & $12.65_{1}^{\mathrm{c}}$ & 1.02 & $1.24_{\mathrm{f}}^{\mathrm{c}}$ & 0.06 & $415278_{1}^{a}$ & 45632 \\
\hline \multirow{3}{*}{$\begin{array}{l}\text { Lemon } \\
\& \text { honey }\end{array}$} & beef & $1435.25_{1}^{\mathrm{a}}$ & 69.15 & $22.24_{1}^{\mathrm{a}}$ & 1.06 & $2.31_{1}^{\mathrm{b}}$ & 0.09 & $175259_{2}^{c}$ & 15417 \\
\hline & wild boar & $1146.08_{1}^{\mathrm{b}}$ & 49.20 & $18.07_{1}^{\mathrm{b}}$ & 0.94 & $2.65_{1}^{\mathrm{a}}$ & 0.06 & $246157_{2}^{\mathrm{b}}$ & 9650 \\
\hline & roe deer & $924.15_{1}^{c}$ & 35.48 & $12.60_{1}^{c}$ & 0.57 & $1.20_{1}^{\mathrm{c}}$ & 0.04 & $365771_{2}^{a}$ & 38740 \\
\hline \multirow{3}{*}{$\begin{array}{l}\text { Balsamic } \\
\text { vinegar }\end{array}$} & beef & $1374.15_{1}^{\mathrm{a}}$ & 69.50 & $22.31_{1}^{\mathrm{a}}$ & 2.14 & $2.27_{3}^{c}$ & 0.12 & $215412_{1}^{c}$ & 10128 \\
\hline & wild boar & $1138.42_{1}^{\mathrm{b}}$ & 37.44 & $17.78_{1}^{b}$ & 2.03 & $2.61_{1}^{\mathrm{a}}$ & 0.08 & $284117_{7}^{\mathrm{b}}$ & 21400 \\
\hline & roe deer & $916.57_{1}^{\mathrm{c}}$ & 59.41 & $12.48_{1}^{\mathrm{c}}$ & 0.57 & $1.12_{z}^{c}$ & 0.03 & $384706_{2}^{\mathrm{a}}$ & 62849 \\
\hline \multirow{3}{*}{$\begin{array}{l}\text { Pineapple } \\
\text { juice }\end{array}$} & beef & $1361.48_{1}^{\mathrm{a}}$ & 72.15 & $21.80_{1}^{\mathrm{a}}$ & 1.10 & $2.05_{2}^{\mathrm{b}}$ & 0.10 & $148215_{2}^{\mathrm{c}}$ & 12471 \\
\hline & wild boar & $1092.50_{1}^{\mathrm{b}}$ & 43.10 & $16.42_{1}^{b}$ & 1.31 & $2.38_{2}^{\mathrm{a}}$ & 0.13 & $256410_{2}^{\mathrm{b}}$ & 10638 \\
\hline & roe deer & $884.14_{1}^{c}$ & 37.05 & $10.79_{1}^{c}$ & 1.28 & $1.01_{3}^{\mathrm{c}}$ & 0.03 & $511326_{1}^{\mathrm{a}}$ & 62001 \\
\hline \multirow{4}{*}{$\begin{array}{l}\text { Ginger } \\
\text { juice }\end{array}$} & beef & $1399.48_{1}^{\mathrm{a}}$ & 84.11 & $22.06_{1}^{\mathrm{a}}$ & 1.96 & $2.20_{1}^{\mathrm{b}}$ & 0.05 & $98415_{3}^{\mathrm{c}}$ & 11326 \\
\hline & wild boar & $1086.15_{1}^{\mathrm{b}}$ & 51.23 & $17.04_{1}^{b}$ & 0.65 & $2.45_{1}^{\mathrm{a}}$ & 0.09 & $302145_{1}^{b}$ & 27652 \\
\hline & roe deer & $916.48_{1}^{c}$ & 32.18 & $12.04_{1}^{c}$ & 0.31 & $1.14_{2}^{\mathrm{c}}$ & 0.02 & $465023_{1}^{a}$ & 58124 \\
\hline & \multicolumn{3}{|c|}{ Significance of interactions } & \multicolumn{2}{|c|}{ M } & \multicolumn{2}{|c|}{$\mathrm{S}$} & \multicolumn{2}{|c|}{$\mathrm{M} \times \mathrm{S}$} \\
\hline \multicolumn{4}{|c|}{ Muscle fibre cross-sectional area, $\mu \mathrm{m}^{2}$} & \multicolumn{2}{|c|}{-} & \multicolumn{2}{|c|}{$*$} & \multicolumn{2}{|c|}{-} \\
\hline \multicolumn{4}{|c|}{ Perimysium thickness, $\mu \mathrm{m}$} & \multicolumn{2}{|c|}{-} & \multicolumn{2}{|c|}{$*$} & \multicolumn{2}{|c|}{-} \\
\hline \multicolumn{4}{|c|}{ Endomysium thickness, $\mu \mathrm{m}$} & \multicolumn{2}{|c|}{$*$} & \multicolumn{2}{|c|}{ * } & \multicolumn{2}{|c|}{-} \\
\hline \multicolumn{4}{|c|}{ Intramuscular fat area, $\mu \mathrm{m}^{2}$} & \multicolumn{2}{|c|}{-} & \multicolumn{2}{|c|}{-} & \multicolumn{2}{|c|}{-} \\
\hline
\end{tabular}

Estimated means in columns marked with different superscripts are different $(P \leq 0.05)$.

Estimated means in row marked with different subscripts are different $(P \leq 0.05)$.

Significance of interactions $-\mathrm{M}$ (marinade), $\mathrm{S}$ (meat species): - no interaction, ${ }^{*} P \leq 0.05, * * P \leq 0.01$.

but it has been suggested that marinating may reduce the thermal stability of connective tissue (Lewis and Purslow, 1991), which was visible in our study as a decrease in perimysium and endomysium thickness of meat snacks after drying. The effects of ginger marinade on the structural elements of jerky was also revealed in our research, but it was lower than those that occurred when pineapple was used in meat snack production. Lee et al. (1986) explained that a higher concentration of ginger extract extensively degraded the myofibrils and the degradation appeared to begin at I band of each sarcomere and progressed towards the $\mathrm{M}$ line. According to Naveena and Mendiratta (2001), this enzyme has a greater proteolytic activity in heated conditions, which is desirable. In our case, the effects of ginger marinade on the structural elements of jerky was lower than pineapple, which can be assigned to both the lower activity of those enzyme 
as compared to bromelain or less additive than that applied by other researchers. Furthermore, Naveena and Mendiratta (2001) used a ginger extract, not a raw ginger juice as in our study. When the vinegar and lemon $\&$ honey marinades were applied, insignificant smaller differences in fibre CSA and in connective tissue thickness were observed compared to the control sample of jerky. Thus, in this case, marinating caused the greatest changes for endomysium compared to other structure elements. Moreover, Gault (1991) and Burke and Monaham (2003) found that meat which had been soaked in acidic marinades and consequently had a $\mathrm{pH}$ below
5.0 took in water and became less tough. The action mechanism of acidic marinades such as vinegar and lemon \& honey is believed to involve several factors including the weakening of structures due to the swelling of meat, increased proteolysis by cathepsins and increased conversion of collagen to gelatin at a low $\mathrm{pH}$ during thermal treatment (Berge et al., 2001).

In our study more intensive changes in endomysium thickness than other structural elements were visible. Differences in muscle structure could be connected with differences in the WB parameters and sensory properties of jerky (Table 2, Fig. 1).

Table 2. Mean values of Warner-Bratzler parameters of beef, wild boar and roe deer jerky produced with different marinades

\begin{tabular}{|c|c|c|c|c|c|}
\hline \multirow[t]{2}{*}{ Marinade } & \multirow[t]{2}{*}{ Meat species } & \multicolumn{2}{|c|}{$\begin{array}{c}\text { Shear force } \\
\text { N }\end{array}$} & \multicolumn{2}{|c|}{$\begin{array}{c}\text { Work ratio } \\
\mathrm{J}\end{array}$} \\
\hline & & mean & SD & mean & SD \\
\hline \multirow[t]{3}{*}{ Spices } & beef & $168.37_{1}^{a}$ & 6.32 & $1.825_{1}^{\mathrm{a}}$ & 0.174 \\
\hline & wild boar & $162.17_{1}^{a}$ & 7.12 & $1.769_{1}^{\mathrm{a}}$ & 0.125 \\
\hline & roe deer & $137.00_{1}^{\mathrm{b}}$ & 5.21 & $1.490_{1}^{\mathrm{b}}$ & 0.112 \\
\hline \multirow[t]{3}{*}{ Lemon \& honey } & beef & $149.83_{z}^{a}$ & 6.14 & $1.812_{1}^{\mathrm{a}}$ & 0.201 \\
\hline & wild boar & $139.00_{2}^{\mathrm{b}}$ & 3.16 & $1.479_{z}^{b}$ & 0.142 \\
\hline & roe deer & $118.00_{2}^{c}$ & 7.41 & $1.430_{1}^{\mathrm{b}}$ & 0.117 \\
\hline \multirow[t]{3}{*}{ Balsamic vinegar } & beef & $154.50_{2}^{\mathrm{a}}$ & 3.15 & $1.728_{4}^{\mathrm{a}}$ & 0.230 \\
\hline & wild boar & $142.00_{2}^{\mathrm{b}}$ & 6.21 & $1.629_{2}^{\mathrm{a}}$ & 0.108 \\
\hline & roe deer & $119.00_{2}^{\mathrm{c}}$ & 4.65 & $1.326_{1}^{\mathrm{b}}$ & 0.115 \\
\hline \multirow[t]{3}{*}{ Pineapple juice } & beef & $129.33_{4}^{\mathrm{a}}$ & 9.18 & $1.409_{2}^{\mathrm{a}}$ & 0.137 \\
\hline & wild boar & $124.00_{3}^{\mathrm{a}}$ & 3.32 & $1.204_{4}^{\mathrm{a}}$ & 0.101 \\
\hline & roe deer & $70.33_{4}^{b}$ & 5.60 & $0.970_{2}^{\mathrm{b}}$ & 0.078 \\
\hline \multirow[t]{3}{*}{ Ginger juice } & beef & $142.60_{3}^{\mathrm{a}}$ & 2.87 & $1.597_{7}^{\mathrm{a}}$ & 0.127 \\
\hline & wild boar & $133.33_{7}^{\mathrm{a}}$ & 8.41 & $1.317^{\mathrm{b}}$ & 0.096 \\
\hline & roe deer & $103.83_{3}^{b}$ & 4.55 & $1.221_{1}^{\mathrm{b}}$ & 0.140 \\
\hline \multicolumn{2}{|c|}{ Significance of interactions } & M & $\mathrm{S}$ & \multicolumn{2}{|c|}{$\mathrm{M} \times \mathrm{S}$} \\
\hline \multicolumn{2}{|l|}{ Shear force, $\mathrm{N}$} & $*$ & $*$ & \multicolumn{2}{|c|}{-} \\
\hline \multicolumn{2}{|l|}{ Work ratio, $\mathrm{J}$} & - & $*$ & \multicolumn{2}{|c|}{-} \\
\hline
\end{tabular}

Estimated means in columns, marked with different superscripts are different $(P \leq 0.05)$.

Estimated means in row, marked with different subscripts are different $(P \leq 0.05)$.

Significance of interactions $-\mathrm{M}$ (marinade), $\mathrm{S}$ (meat species): - no interaction, ${ }^{*} P \leq 0.05,{ }^{* *} P \leq 0.01$. 
A
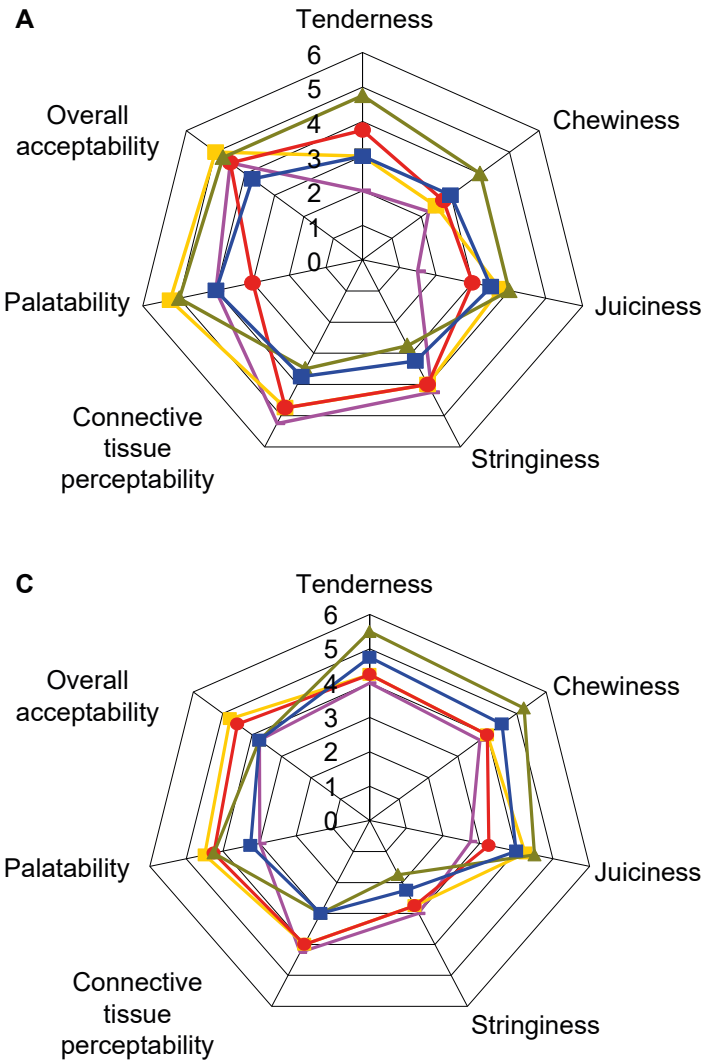

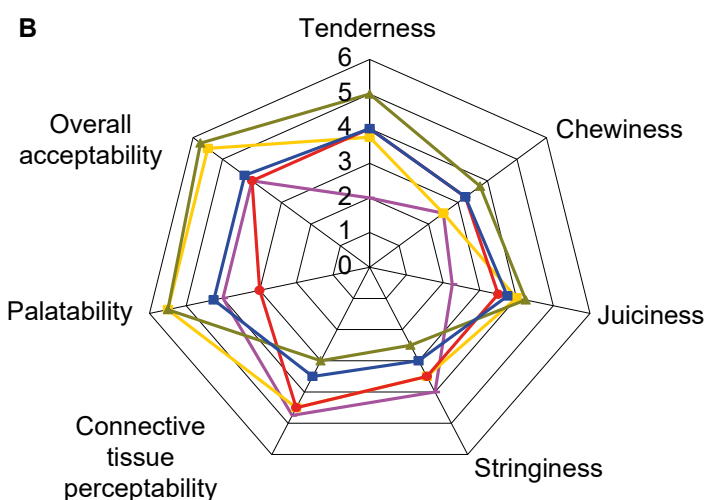

tissue
perceptability

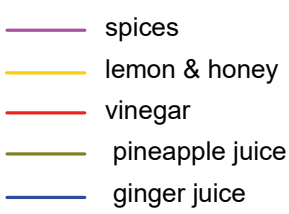

Fig. 1. Sensory properties of beef(A), wild boar (B) and roe deer (C) jerky produced with different marinades

The highest values of shear force, work ratio and stringiness, and also the lowest tenderness and juiciness were recorded in beef jerky - the meat consisted of big muscle fibres and thick perimysium. Wild boar jerky typically has lower values of WB parameters, higher tenderness and juiciness, as well as the highest palatability and overall acceptability, and at the same time smaller muscle fibres than beef jerky but the thickest endomysium. The lowest WB test parameters, stringiness, connective tissue perceptibility, palatability and overall acceptability, along with the highest tenderness and juiciness were found in roe deer jerky, a product initially with the most delicate structure with the highest amount of intramuscular fat. It was also shown that compared to wild boar and beef, roe deer jerky with spices received worse scores for palatability and overall acceptability because of the higher perceptibility of venison's characteristic odour. Marinating applied before drying, regardless of the method, resulted in a reduction in the jerky's shear force and work ratio, as well as stringiness, connective tissue perceptability. It also led to an improvement in juiciness, tenderness, chewiness, palatability and overall acceptability compared to the sample produced only with the addition of spices. The results collected in this part of the study indicate that the changes in WB parameter values were dependent on the meat species and in the case of shear force, also on the marinating method. A comparison of the three different species showed that the generally tender roe deer jerky compared to beef and wild boar snacks was the most susceptible to WB and sensory parameters changes after marinating. For example, differences in WB parameters between seasoning jerky and other marinated products were highest for snacks obtained from roe deer meat, and ranged from $13-49 \%$ for shear force and from $4-35 \%$ for work ratio, regardless of the marinating methods. At the same time, changes between the samples of jerky produced from wild boar meat were about $12-24 \%$ and $4-35 \%$ and for beef snacks about $8-23 \%$ and $1-22 \%$, 
respectively (Table 2). When the marinating methods were compared, the lower decrease in WB parameters was observed in samples of jerky produced using lemon \& honey and balsamic vinegar marinades, and a higher one when the pineapple and ginger was applying before drying, compared to products with the addition of spices. For example, the shear force of jerky with lemon \& honey and balsamic vinegar marinades had decreased by about $8-14 \%$, whereas the addition of marinades with exogenous plant enzymes such as bromelain from raw pineapple and zingabaine from ginger produced a $23-49 \%$ and $16-25 \%$ reduction in shear force relative to the control, respectively, depending on the meat species (seasoning jerky). At the same time, changes in work ratio were about $1-16 \%$, $11-35 \%$ and $13-25 \%$, respectively (Table 2). One of the possibilities for increasing shear force and work ratio is the optimal $\mathrm{pH}$ for the activity of cathepsins in range 3.5-5.0 and hence the lowering of meat $\mathrm{pH}$ in marinades may well enhance proteolytic attack by these enzymes (Burke and Monahan, 2003), which is visible in samples of roe deer, wild boar and beef meat marinated before drying with lemon juice and balsamic vinegar addition. As Figure 1 shows, adding those ingredients as well as improving the mechanical properties of dried meat snacks effected a significant improvement in the tenderness $(P<0.05)$, juiciness $(P<0.001)$, connective tissue perceptibility $(P<0.01)$ and palatability $(P<0.05)$ of jerky, especially when produced using venison.

Sensory evaluation also confirmed that the characteristically high perceptibility of venison odour, especially typical for roe deer meat, almost disappeared during the marinating process, in particular when dipped into lemon \& honey and vinegar marinades. The enzymatic marinades applied for meat tenderization and flavoring also led to an improvement in the hydrophilic characteristic of the meat protein (Oreskovich et al., 1992), and thus had a higher tenderness, chewiness, juiciness, lower stringiness and connective tissue perceptibility. Moreover, better scores were registered for palatability and overall acceptability than for jerky dried only after seasoning. According to Ionescu et al. (2008), bromelain showed hydrolytic activity on the connective tissue, leading to the better tenderization of tough meat. Those results were confirmed by Żochowska-Kujawska et al. (2012), who found that even very hard wild boar muscles, such as Biceps femoris and Semimembranosus, soaked in marinades made from fresh pineapple juice were characterized by the worst sensory properties, probably as a consequence of the deepest changes in structure elements. A sensory panel also detected improvements in sensory properties when the ginger marinade was applied before drying, although the effects of those marinades on jerky quality were lower than for the pineapple marinade.

\section{CONCLUSIONS}

The results obtained in this experiment indicate how marinades applied before drying affect the structure and thus the mechanical properties and sensory properties of meat snacks produced from beef and venison. Our results showed the more pronounced effect of pineapple and ginger marinades on structure and thus on shear force and sensory properties compared with other marinades. Sensory analysis showed that samples of venison, especially roe deer meat, treated with acid marinades such as lemon \& honey and balsamic vinegar were rated as superior and most preferred by the panelists, which can be attributed to the high tenderness and low detectability of venison odour, which almost disappears in the marinating process. Marinades containing proteolytic enzymes or characterized by low $\mathrm{pH}$ could be used as tenderizers in jerky produced from initially tough meat, such as wild boar. Marinades based on lemon \& honey and also vinegar could be used for flavoring tender meat with an intense aroma.

\section{REFERENCES}

Albright, S. N., Kendall, P. A., Sofos, J. N. (2000). Sensory properties of beef jerky processed under various conditions. In Proceedings of IFT annual meeting. June 1014, 2000. Session 11. Dallas, TX, USA.

Ashie, I. N. A., Sorensen, T. L., Nielsen, P. M. (2002). Effect of papain and a microbial enzyme on meat proteins and beef tenderness. J. Food Sci., 67, 2138-2142. http:// dx.doi.org/10.1111/j.1365-2621.2002.tb09516.x

Berge, P., Ertbjerg, P., Larsen, L. M., Astruc, T., Vignon, X., Moller, A. J. (2001). Tenderization of beef by lactic acid injected at different times post mortem. Meat Sci., 57, 347-357. 
Żochowska-Kujawska, J., Kotowicz, M., Lachowicz, K., Sobczak, M. (2017). Influence of marinades on shear force, structure and sensory properties of home-style jerky. Acta Sci. Pol. Technol. Aliment., 16(4), 413-420. http://dx.doi.org/10.17306/J.AFS.2017.0508

Bourne, M. C. (1982), Food texture and viscosity. New York: Academic Press.

Burck, H. Ch. (1975). Utrwalanie [Fixation]. In Technika histologiczna (pp. 62-63). PZWL: Warszawa [in Polish].

Burke, R. M., Monahan, F. J.(2003). The tenderization of shin beef using a citrus juice marinade. Meat Sci., 63, 161168. http://dx.doi.org/10.1016/S0309-1740(02)00062-1

Gault, N. F. S. (1991). Marinated meat. In R. Lawrie (Ed.), Developments in meat science (vol. 5, pp. 191-245). London: Elsevier Science.

Ionescu, A., Aprodu, I., Pascaru, G. (2008). Effect of papain and bromelin on muscle and collagen proteins in beef meat. Annal. Univ. Dunarea Galati Fascicle VI, Food Techn., 31, 9-16.

Ketnawa, S., Rawdkuen, S., Chaiwut, P. (2010). Two phase partitioning and collagen hydrolysis of bromelain from pineapple peel Nang Lae cultivar. Biochem. Eng., J., 52, 205-211. http://dx.doi.org/10.1016/j.bej.2010.08.012

Konieczny, P., Kowalski, R., Pyrcz, J. (2004). Selected quality attributes of dried snack foods made from beef. Żywn. Nauka Techn. Jakość, 3(40), 32-39.

Konieczny, P., Stangierski, J., Kijowski, J. (2007). Physical and chemical characteristics and acceptability of home style beef jerky. Meat Sci., 76, 253-257. http://dx.doi. org/10.1016/j.meatsci.2006.11.006

Lee, Y. B., Sehnert, D. J., Ashmore, C. R. (1986). Tenderization of meat with ginger rhizome protease. J. Food Sci., 51, 1558-1559. http://dx.doi.org/10.1111/j.1365-2621. 1986.tb13860.x

Lewis, G. J., Purslow, P. P. (1991). The effect of marination and cooking on the mechanical properties of intramuscular connective tissue. J. Muscle Foods, 2, 177-195. http://dx.doi.org/10.1111/j.1745-4573.1991.tb00452.x

Naveena, B. M., Mendiratta, S. K. (2001). Tenderization of spent hen meat using ginger extract. Br. Poultry Sci., 42, 3, 344-350. http://dx.doi.org/10.1080/0007166012005 5313

Oreskovich, D. C., Bechtel, P. J., McKeith, F. K., Novakofski, J., Basgall, E. J. (1992). Marinade $\mathrm{pH}$ affects textural properties of beef. J. Food Sci., 57, 305-311. http:// dx.doi.org/10.1111/j.1365-2621.1992.tb05482.x
Paleari, M. A., Beretta, G., Colombo, F., Foschini, S., Bertolo, G., Camisasca, S. (2000). Buffalo meat as a salted and cured product. Meat Sci., 54, 365-367. http://dx.doi. org/10.1016/S0309-1740(99)00111-4

Sales, J., Kotrba, R. (2013). Meat from wild boar (Sus scro$f a$ L.): A review. Meat Sci., 94, 187-201. http://dx.doi. org/10.1016/j.meatsci.2013.01.012

Scheinberg, J. A., Svoboda, A. L., Cutter, C. N. (2014). High-pressure processing and boiling water treatments for reducing Listeria monocytogenes, Escherichia coli O157:H7, Salmonella spp., and Staphylococcus aureus during beef jerky processing. Food Contr., 39, 105-110. http://dx.doi.org/10.1016/j.foodcont.2013.11.002

Sloan, A. (2011). Top 10 food trends. J. Food Technol., 65(49), 24-40.

Soriano, A., Cruz, B., Gómez, L., Mariscal, C., García-Ruiz, A. (2006). Proteolysis, physicochemical characteristics and free fatty acid composition of dry sausages made with deer (Cervus elaphus) or wild boar (Sus scrofa) meat: A preliminary study. Food Chem., 96, 173-184. http://dx.doi.org/10.1016/j.foodchem.2005.02.019

Wada, M., Suzuki, T., Yaguti, Y., Hasegawa, T. (2002). The effect of pressure treatments with kiwi fruit protease on adult cattle semitendinosus muscle. Food Chem., 78(2), 167-171. http://dx.doi.org/10.1016/S0308-8146 (01)00395-8

Żochowska-Kujawska, J., Lachowicz, K., Sobczak, M. (2012). Effects of fibre type and kefir, wine lemon, and pineapple marinades on texture and sensory properties of wild boar and deer longissimus muscle. Meat Sci., 92, 675-680. http://dx.doi.org/10.1016/j.meatsci. 2012.06.020

Żochowska-Kujawska, J., Sobczak, M., Lachowicz, K. (2009). Comparison of the texture, rheological properties and myofibre characteristics of SM (semimembranosus) muscle of selected species of game animals. Pol. J. Food Nutr. Sci., 59(3), 243-246. 